striations. Fresh fractures are shiny. They contain numerous small bubbles and metallic spherules, which on mieroprobe analysis proved to be of iron. Nickel was not detected. They were found near Hearhof, Pflaumloch and Röttingen. Spectrochemical analysis of one specimen showed 53 per cent $\mathrm{SiO}_{2}, 18$ per cent $\mathrm{Al}_{2} \mathrm{O}_{3}, 26$ por cent $\mathrm{CaO}, 2.3$ per cent $\mathrm{MgO}, 0.90$ per cent $\mathrm{Fe}_{2} \mathrm{O}_{3}, 0.85$ per cent $\mathrm{TiO}_{2}, 0.037$ per cent $\mathrm{V}_{2} \mathrm{O}_{5},<0.01$ per cent $\mathrm{NiO},<0.01$ per cent $\mathrm{CuO}$ and $<0.5$ per cent $\mathrm{Na}_{2} \mathrm{O}$. The $\mathrm{K}_{2} \mathrm{O}$ was not determined. Refractive index was variable. Two specimens yielded $1 \cdot 576$ and $1 \cdot 588$. These results are outside the range of known tektites.

In order to make sure that we are not dealing with some new type of tektites, we made a qualitative dating of all our specimens by the fission track method of Fleischer and Price $^{2}$. This method is vory simple and lends itself admirably to qualitative datings, in which the determination of the uranium concentration is dispensed with.

Small chips of glass were crushed to splinters of about $0.5 \mathrm{~mm}$ size. These wore then etched for $15-45 \mathrm{sec}$ in 48 per cent hydrofluoric acid. A moldavite tektite of known age, 14.7 million years, which is contemporary with Ries Kessel formation ${ }^{3}$, served as a control. After etching, the moldavite showed under optical microscope of 600 times magnification, quite a few typical teardrop, elliptical and pointed etchpits which are due to fossil fission tracks, whereas the glassy objects did not show any.

We must, therefore, conclude that the objects we found aro recent glasses. They may be an iron furnace slag, although there seoms to be no iron industry at present near Ries Kessel.

This work was supported by U.S. National Science Foundation research grant $G P-139$. We thank J. and W. Kavasch for field assistance.

$$
\begin{aligned}
& \text { V. VAND } \\
& \text { F. DACHULE } \\
& \text { P. Y. Srmons }
\end{aligned}
$$

Materials Research Laboratory and

Department of Geochemistry and Mineralogy, Pennsylvania State University, University Park.

${ }^{1}$ Kavasch, J. (personal communication).

Fleiseher, R. L., and Price, P. B., Glass Dating by Fission Fragment Tracks, Rep. No. 63-RL-3424M (General Electric Res. Lab., Sept. 1963). ${ }^{3}$ Gentner, W., Lippolt, H. J., and Schaeffer, O. A., Geochim. Cosmochim. Acta, 27, 191 (1963).

\section{Analysis of Geological Samples by Spark Source Mass Spectrometry}

IT has been found possiblo to apply spark source mass spectrometry to the estimation of trace elements in the two standard rock samples granite $G 1$ and diabase $W 1$ (originating from the U.S. Geological Survey, Washington). These samples have already been analysed many times, but by other analytical techniques such as emission spectroscopy, neutron activation, polarography, flame photometry and chemical methods (seo Fleischer and Stevens ${ }^{1}$ ). However, the irreproducibility of results for some elemonts by these techniques and the lack of data for other elements prompted this preliminary work on the application of spark source mass spectrometry to this analysis.

The instrument used for the work was the A.E.T. $M S 7$ mass spectrometer, and the samples, after being ground to a fine powder, were compacted into small rod-shaped electrodes ${ }^{2}$. In order to remove any surface contamination which might havo been picked up during this process, the electrodes were sparked for about $5 \mathrm{~min}$ in the spectrometer source before the analysis was carried out in the usual manner ${ }^{3}$. Each sample was analysed twice and silicon was chosen as the internal standard as its concentration in both samples is accurately known. A microdensitometer was used to compare the densities of lines due to the isotopes of the trace elements with that of the line due to the silicon-30 isotope. The concentrations of the elements were estimated by the method of Craig, Errock and Waldron ${ }^{4}$, assuming that all elements have equal sensitivity. Experience has shown that the majority of elements do have the same sensitivity to within a factor of three.

The resuits for elemonts detected are given in Table 1 and limits of detection for elements not detected are given in Table 2. For some elements, there was definite evidence of inhomogeneity of the samples and this has been suspected by other workers ${ }^{1}$. The values in Tables 1 and 2 may be in orror, therefore, by more than a factor of three; but an overall picture of the trace constituents of the two rocks has been obtained and the work has provided a useful guide for future studies.

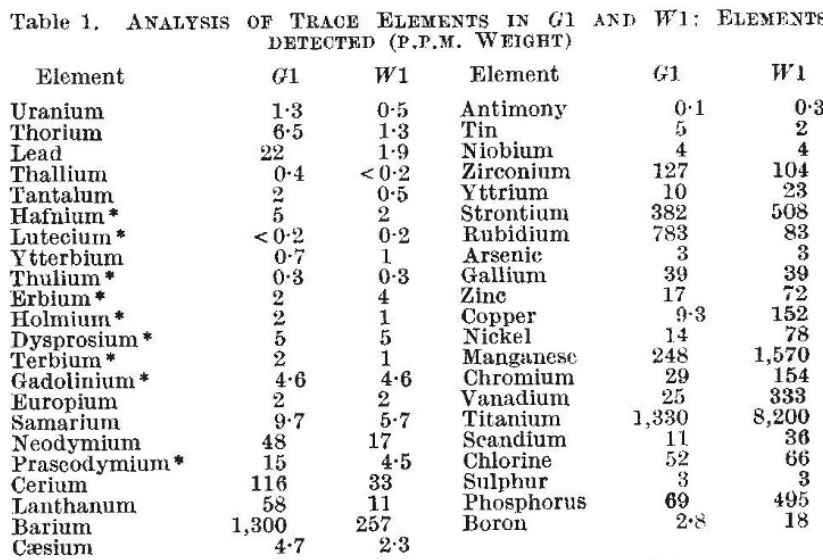

* These elements were not reported by Fleischer and Stevens.

Table 2. ANalYsis of Trace Elements in G1 AND W1: Limits of Table 2. ANALYSIS OF TRACE ELEMENTS IN
DETECTION FOR ELEMENTS NOT DETECTED (P.P.M. W WIiHT)
Element Limit of detection Element Limit of detection Element Limit of $\begin{array}{llll}\text { Bismuth } & 0 \cdot 9 & \text { Indium } & 0 \cdot 2 \\ \text { Mercury } & 0 \cdot 3 & \text { Cadmium } & 0 \cdot 2\end{array}$ Gold

Platinum

Iridium

Osmitum

Thenium Jodine $0 \cdot 08$
$0 \cdot 3$ $0 \cdot 3$
$0 \cdot 2$ Rhodium Molybdenum Jromine Selenium

This mass spectrometric analysis has the advantages of speed, sensitivity and the fact that, in a single analysis, estimates can be made of the concentrations of 66 trace elements in the mass range 7-238. In these experiments, the powdered samples were prepared and the mass spectra obtained in approximately $4 \mathrm{~h}$. Interpretation of the spectra can be carried out visually, in which case the time taken would be about $6 \mathrm{~h}$, or a microdensitometer can be used to give a more precise result when the time required would be about $24 \mathrm{~h}$.

In these experiments, the photoplates were not given the longest possible exposures and, therefore, the highest sensitivity has not yet been achieved. Further work will be carried out to obtain more information and lower detection limits, particularly for the rare earth and higher mass elements.

R. BROWN

W. A. Wolstenholme

Associated Electrical Industries, Ltd., Manchester.

${ }^{1}$ Fleischer, M., and Stevens, R. E., Geochimica et Cosmochimica Acta, 26, 525 (1962).

Brown, R., and Wolstenhelme, W. A., Proc. Eleventh Conf. A.S.T.M. Comm. $E-14$ (1963).

${ }^{3}$ Elliott, R. M., Craig, R. D., and Errock, G. A., Proc. Intern. Instrument and Measurement Conf., Stockholm (1960).

4 Craig, R. D., Frrock, G. A., and Waldron, J. D., Advances in Mass Spectr.metry, edit. by waldron, J. D. (Pergamon Press, 1959). 